\section{Delivery assistance in fetal macrosomia}

\section{Assistência ao parto na macrossomia fetal}

\section{Abstract}

Objectives: to evaluate delivery assistance in $f e$ tal macrosomia.

Methods: this was a hospital-based cohort study of consecutive births at a tertiary perinatal center from January 1, 1996 to October 31, 1999. A total of 5261 pregnancies met the inclusion criteria which were singleton pregnancies with minimal birth weight of $1000 \mathrm{~g}$. Fetal macrosomia was defined as birth weight of $4000 \mathrm{~g}$ or more. We studied the mode of delivery, the newborn condition at birth, considered low when the Apgar scored below seven in the first or fifth minute, and the presence of abnormalities that could indicate a Caesarian section (disproportion, uterine dysfunction, prolonged second period of birth and fetal distress).

Results: 296 (5,6\%) of the babies were macrosomic. Macrosomia was a risk factor for Caesarian section $(R R=1,59, p<0,001)$ and for operative vaginal delivery $R R=1,12(p<0,001)$. Newborn conditions was not worse in macrosomic babies. There was a positive correlation between fetal macrosomia and disproportion but not with uterine dysfunction, prolonged second period of birth or fetal distress.

Conclusions: caesarian section was indicated more often for macrosomic babies, but our data did not suggest that a more extensive use of $C$-Sections was justified.

Key words Fetal macrosomia, Delivery, obstetrics, Infant, newborn
Renato Augusto Moreira de Sá 1

Rita Bernadete Guerios Bornia 2

Alfredo de Almeida Cunha 3

Ludmila Sampaio Sieczko 4

Cristiane Barbosa da Silva 5

Fernanda Campos da Silva 6

1-6 Departamento de Obstetrícia. Maternidade Escola da Universidade Federal do Rio de Janeiro. Rua das Laranjeiras, 180. Rio de Janeiro, RJ, Brasil. CEP: 22.240-002.

\section{Resumo}

Objetivos: avaliar a assistência ao parto na macrossomia fetal.

Métodos: estudo do tipo coorte realizado em centro perinatal terciário no período de 1 de janeiro de 1996 a 31 de outubro de 1999. Foram selecionadas 5261 gestações de acordo com os critérios de inclusão, que foram: gestação única e peso mínimo ao nascimento de $1000 \mathrm{~g}$. A macrossomia fetal foi definida como peso ao nascimento acima de $4000 \mathrm{~g}$. Estudamos a via de parto, as condições ao nascimento, Apgar baixo quando inferior a sete no primeiro $e$ quinto minutos e as anormalidades que serviram de indicação para cesariana (desproporção, distocia uterina, segundo período prolongado e sofrimento fetal).

Resultados: 296 (5,6\%) dos conceptos eram macrossômicos. Macrossomia foi fator de risco para cesariana $(R R=1,59, p<0,001)$ e para parto operatório vaginal $(R R=1,12 p<0,001)$. As condições do recémnascido não foram piores nos fetos macrossômicos. Houve correlação positiva entre macrossomia fetal e desproporção mas não para distocia uterina, prolongamento do segundo período ou sofrimento fetal.

Conclusões: houve maior número de indicações de cesariana para os fetos macrossômicos, mas os dados não sugerem que o uso mais generalizado da cesariana se justifique.

Palavras-chave Macrossomia fetal, Parto obstétrico, Recém-nascido 


\section{Introduction}

Macrosomia is a term used rather imprecisely to describe a large fetus. There is general agreement among obstetricians that newborns weighing less than $4000 \mathrm{~g}$ are not too big. However, a similar consensus does not exist to define fetal macrosomia. Most agree that a baby heavier than $90 \%$ of the estimated birth weight is macrosomic. ${ }^{1}$ It is also of joint consent that a macrosomic baby weighs $4000 \mathrm{~g}$ or more. ${ }^{2}$

The birth weight is an important factor affecting perinatal morbidity and mortality mainly because of fetal asphyxia and birth trauma. ${ }^{3}$ It also affects the maternal prognosis as a result of genital tract trauma and postpartum bleeding. Delivering a big baby can be distressing for mother, baby and obstetric staff.

The incidence of fetal macrosomia is reportedly increasing, and many questions regarding the optimal obstetric management of these babies remain unanswered.4,5 The objective of this study is to evaluate delivery assistance in fetal macrosomia.

The minimum weight that defines macrosomia is controversial (4000 g, $4250 \mathrm{~g}$, and $4500 \mathrm{~g}$ ). The American College of Obstetrics and Gynecologists (ACOG) reported $4500 \mathrm{~g}$ as the cutoff value for macrosomia in 1991. We find that in Brazil, macrosomic babies should be those weighting $4000 \mathrm{~g}$ or more, because of the ethnic characteristics of our population.6,7 In addition to weight, body proportions have a role in defining macrosomia. Disproportional macrosomia is associated with an increased risk of neonatal complications, and is common among infants of diabetic mothers. The risk factors leading to macrosomia must be thoroughly evaluated by the clinician. The most common cause of macrosomia is the increased intrinsic growth potential present in approximately $50-60 \%$ of the cases. Maternal glucose intolerance results in macrosomia in $40 \%$ of the cases. These fetuses are prone fetal asphyxia and birth trauma as well. 8 There are studies reporting that the history of previous macrosomic babies is the leading maternal factor to macrosomia. ${ }^{9}$ A Turkish study revealed that the history of previous macrosomic baby was five times higher in the macrosomic birth group. 8

\section{Methods}

A cohort retrospective study was performed and completed in the Maternidade Escola, of Universidade Federal do Rio de Janeiro, RJ, Brazil. The period of study was between January 1996 and Octo- ber 1999 . We included all singleton pregnancies whose babies weighed $1000 \mathrm{~g}$ or more $(\mathrm{n}=5261)$.

The study group was formed of newborns $4000 \mathrm{~g}$ or heavier and mothers of these babies. All babies weighing between $1000 \mathrm{~g}$ and $3999 \mathrm{~g}$ formed the control group. The information recorded included mode of delivery (vaginal birth, caesarean section or operative vaginal delivery), newborn condition, and the indication of caesarean section. The newborn condition was determined by the Apgar score which was considered low when below seven in the first or fifth minute. The mode of delivery was studied according to newborn condition. We also evaluated the incidence of cephalopelvic disproportion, uterine dysfunction, prolonged second period of labour and fetal distress in macrosomic and non macrosomic fetuses.

Cephalopelvic disproportion was defined as failure of the head to reach the isquial spines one 1 hour after full cervical dilatation. Uterine dysfunction occurred when there was failure to advance in either first or second period of labour, or when cervical dilatation had a progression of less than $1 \mathrm{~cm} / \mathrm{h}$ in the first period of labour despite the use of oxytocin in the absence of malpresentation.

The statistical analysis was performed using a chi-square test and Epi-info 6 package, version 6.04 b, January 1997, with a significant difference between groups determined by a $\mathrm{p}$ value $<0,05$.

\section{Results}

A total of 5261 deliveries of singleton babies weighing more than $1000 \mathrm{~g}$ had been recorded during the study period. The rate of macrosomic deliveries, was 5,6\% $(n=296 / 5261)$. The overall rate of caesarian section was of $2073(39,4 \%)$, spontaneous birth was achieved in $3064(58,2 \%)$ and operative vaginal delivery in $124(2,4 \%)$. Totally, the outcome $(3064+$ $124=3188) 60,6 \%$ of pregnancies was vaginal delivery.

In the control group, $1894(38,2 \%)$ of pregnancies ended by caesarian section and (2955 spontaneous +116 operative $=3071) 61,8 \%$ (achieved vaginal delivery. The macrosomic group had a higher rate of caesarian section $(R R=1,59, p<0,001)$ and of operative vaginal delivery $(\mathrm{RR}=1,12 \mathrm{p}<0,001)$. In this group, $179(60,5 \%)$ of babies were delivered by caesarian section, $109(36,8 \%)$ by spontaneous vaginal delivery and $8(2,7 \%)$ by operative vaginal delivery (Table 1). 
Outcome of labour in macrosomic and non-macrosomic babies.

\begin{tabular}{|c|c|c|c|c|c|c|c|c|}
\hline & \multicolumn{2}{|c|}{ Spontaneous vaginal } & \multicolumn{2}{|c|}{ Caesarean section } & \multicolumn{2}{|c|}{ Operative vaginal } & \multicolumn{2}{|c|}{ Total } \\
\hline & $\mathrm{n}$ & $\%$ & $\mathrm{n}$ & $\%$ & $\mathrm{n}$ & $\%$ & $\mathrm{n}$ & $\%$ \\
\hline Macrosomic & 109 & 36,8 & 179 & 60,5 & 8 & 2,7 & 296 & 100,0 \\
\hline Non macrosomic & 2955 & 59,5 & 1894 & 38,2 & 116 & 2,3 & 4965 & 100,0 \\
\hline Total & 3064 & 58,2 & 2073 & 39,4 & 124 & 2,4 & 5261 & 100,0 \\
\hline
\end{tabular}

The Apgar score was checked in the first and in the fifth minute. In the first minute was checked, it was below seven in $12,4 \%$ of all babies and in the fifth minute in $2,1 \%$. We did not find a higher risk of Apgar score below seven in the first and in the fifth minute when we compared the macrosomic to the normal weight $(2500-3999 \mathrm{~g})$, stratified by mode of delivery. The incidence of low Apgar score in the first minute at the control group was $12,3 \%(\mathrm{n}=$ 598/4862) and in the study group (macrossomic) the incidence was of $14,6 \%(n=43 / 294)$. When considering the fifth minute, $3,1 \%(n=9 / 295)$ macrosomic babies and 2,0\% $(n=99 / 4897)$ normal babies had an Apgar score below seven.
Three hundred and eighteen babies with an Apgar score below seven were delivered by caesarian section in the first minute. When comparing the control group with the study group, we did not find a statistically significant difference between them since it was of $15,1 \%$ in macrosomic babies and of $15,5 \%$ in normal babies. The vaginal delivery was achieved in 323 babies born with a low Apgar score in the first minute. Again, the difference between the two groups was not statistically significant, $13,9 \%$ in the study group and $10,3 \%$ in the control group.

In babies with a low Apgar score in the fifth minute, there was not a statistically significant difference between abdominal and vaginal delivery for macrossomic babies $(R R=2,31 ; p=0,10)$. (Table 2).

Macrosomia, newborn condition at birth and outcome of delivery.

\begin{tabular}{|c|c|c|c|c|c|c|c|c|c|c|c|c|}
\hline & \multicolumn{6}{|c|}{ Apgar $<7$ in the first minute } & \multicolumn{6}{|c|}{ Apgar $<7$ in the fifth minute } \\
\hline & \multicolumn{2}{|c|}{ Vaginal } & \multicolumn{2}{|c|}{ Caesarean } & \multicolumn{2}{|c|}{ Total } & \multicolumn{2}{|c|}{ Vaginal } & \multicolumn{2}{|c|}{ Caesarean } & \multicolumn{2}{|c|}{ Total } \\
\hline & $\mathrm{n}$ & $\%$ & $\mathrm{n}$ & $\%$ & $\mathrm{n}$ & $\%$ & $\mathrm{n}$ & $\%$ & $\mathrm{n}$ & $\%$ & $\mathrm{n}$ & $\%$ \\
\hline Macrosomic & $16 / 115$ & 13,9 & $27 / 179$ & 15,1 & $43 / 294$ & 14,6 & $4 / 116$ & 3,4 & $5 / 179$ & 2,8 & $9 / 295$ & 3,1 \\
\hline Non macrosomic & $307 / 2984$ & 10,3 & 291878 & 15,5 & $598 / 4862$ & 12,3 & $45 / 3016$ & 1,5 & $54 / 1861$ & 2,9 & $99 / 4897$ & 2,0 \\
\hline Total & $323 / 3099$ & 10,4 & $318 / 2057$ & 15,5 & $641 / 5156$ & 12,4 & $49 / 3132$ & 1,6 & $59 / 2060$ & 2,9 & $108 / 5192$ & 2,1 \\
\hline $\operatorname{RR}(95 \% \mathrm{Cl})$ & \multicolumn{2}{|c|}{$1,35(0,85-2,16)$} & \multicolumn{2}{|c|}{$0,97(0,68-1,40)$} & & & \multicolumn{2}{|c|}{$2,31(0,85-6,32)$} & \multicolumn{2}{|c|}{$0,97(0,39-2,40)$} & & \\
\hline$p$ value & \multicolumn{2}{|c|}{0,21} & \multicolumn{2}{|l|}{0,88} & & & \multicolumn{2}{|c|}{0,10} & \multicolumn{2}{|c|}{0,86} & & \\
\hline
\end{tabular}

$\operatorname{RR}(95 \% \mathrm{Cl})=$ Risk Ratio $(95 \%$ Confidence interval). 
There was a positive correlation between fetal macrosomia and disproportion $(\mathrm{RR}=3,45, \mathrm{p}<0,001)$ since in that group $15,2 \%$ of babies had the diagnosis compared with $4,4 \%$ in the control group. The same association was not found, however, when fetal distress, uterine dysfunction or prolonged second period of labour in the two groups were analyzed. Fetal distress was diagnosed in $6,4 \%$ of macrosomic babies and in $5,1 \%$ of the remaining babies $(p=0,31)$. One hundred and twenty eight of the total deliveries had a prolonged second period. There was not a sig- nificant difference in that incidence in the two groups, being of $2,4 \%$ in the control group and of $2,7 \%$ in the study group. The same is true when the incidence of uterine dysfunction was compared. One $(0,3 \%)$ macrosomic baby had uterine dysfunction while $24(0,5 \%)$ of the babies in the control group had it. The outcome of delivery was different when uterine dysfunction was diagnosed. The rate of caesarian section was of $64 \%$ in that group and of $39,3 \%$ in cases without uterine dysfunction $(\mathrm{p}<0,05)$ (Table 3).

Distribution of intrapartum and perinatal complications.

\begin{tabular}{|c|c|c|c|c|c|c|}
\hline & \multicolumn{2}{|c|}{$\begin{array}{l}\text { Macrosomic } \\
(N=296)\end{array}$} & \multicolumn{2}{|c|}{$\begin{array}{l}\text { Non macrosomic } \\
\qquad(N=4965)\end{array}$} & \multicolumn{2}{|c|}{$\begin{array}{c}\text { Total } \\
(\mathrm{N}=5261)\end{array}$} \\
\hline & $\mathrm{n}$ & $\%$ & $\mathrm{n}$ & $\%$ & $\mathrm{n}$ & $\%$ \\
\hline Disproportion & 45 & 15,2 & 219 & 4,4 & 264 & 5,0 \\
\hline Uterine dysfunction & 1 & 0,3 & 24 & 0,5 & 25 & 0,5 \\
\hline Prolonged labour & 8 & 2,7 & 120 & 2,4 & 128 & 2,4 \\
\hline Fetal distress & 19 & 6,4 & 253 & 5,1 & 272 & 5,2 \\
\hline
\end{tabular}

\section{Discussion}

Macrosomia is associated with an increased risk of trauma to the maternal birth canal and the fetus. Among these are third and fourth degree perineal tears, difficult instrumental and or operative deliveries, increased postnatal stay in the hospital, need for blood transfusions, shoulder dystocia, fetal asphyxia, fetal injuries, fetal fractures of clavicle and humerus. All of these can be responsible for long-term physical and psychological ill health in these mothers. In addition, fetal complications lead to an increased stay in neonatal unit. This together with medicolegal implications of all of the above lead to a huge financial drain on health care system.

Certain complications like disproportion, uterine dysfunction, prolonged second period of labor, fetal distress and increased risk for caesarean section are more common among macrosomic fetuses, regardless of the exact cause of macrosomia.

The incidence of macrosomia was 296/5261 $(5,6 \%)$ in our population. This is lower than previously reported in the literature (7-10\%).10
Despite the association between birth weight and shoulder dystocia, most authors do not advocate elective caesarean section for macrosomia. Elective caesarean section is not desirable, because it requires a great number of unnecessary procedures to avoid a single neonatal injury. Furthermore the sensitivity of the ultrasound examination in predicting macrosomia is limited, 11 with a low positive predictive value. 12 The palpation and symphysial fundal height measurements appear to be the most reliable method with a predictive value of $50 \% .12$ Some authors asseverate that the prediction power for macrosomia is similar between clinical and ultrasound measurements. ${ }^{13}$ Essentially the predictability of macrosomia is poor and thus unhelpful in the management of these patients.

The prevalence of caesarean section is about $60 \%$ in our data. This is higher than the literature. 12,14 Comparison between our results and that of Varaldi ${ }^{14}$ (as showed in Table 4) indicates differences for caesarean section, labor duration and 5' Apgar score. 
Comparison between our results and Varaldi's

\begin{tabular}{lll}
\hline Information recorded & This study & Varaldi \\
\hline Prevalence & $5,6 \%(296 / 5261)$ & $7,5 \%(392 / 5252)$ \\
Caesarian section & $60,5 \%(179 / 269)$ & $29,5 \%(116 / 392)$ \\
Prolonged 2nd period & $2,4 \%(128 / 5261)$ & $1,1 \%(63 / 5252)$ \\
1' Apgar score & No influence between groups & No influence between groups \\
5' Apgar score & Statistically significant difference between & No influence between groups \\
\hline
\end{tabular}

The majority of perinatologists states that macrosomia itself, without maternal diabetes, is not an indication for caesarean delivery, but added complications, such as breech presentation, prolonged labour and fetal hypoxia, may warrant a caesarean section. Several studies have shown that expectant management is best in clinically suspected macrosomia. 15,16

There was been an argument over the relation between asphyxia and macrosomia. Though there are many studies reporting that does not exist an increased risk of asphyxia and meconium aspiration in macrosomic births, there are some studies claiming the opposite. 17 In our study there was not a statistically significant difference between abdominal and vaginal delivery when comparing the two groups for vaginal deliveries.

The prevalence of prolonged second period is about $1 \%$ in Varaldi's data. In our study, the prevalence of prolonged second period was higher.

In conclusion the caesarian section was indicated more often in macrosomic babies, but our data did not suggest that the wider use of caesarian was justified.

\section{References}

1. Lavin JPJr, Lovelace DR, Miodovnik M, Knowles HC, Barden TP. Clinical experience with one hundred seven diabetic pregnancies. Am J Obstet Gynecol 1983; 147: 74252.

2. Body ME, Usher RH, McLean FH. Fetal macrosomia: prediction, risks, proposed management. Obstet Gynecol 1983; 61: 715-22.

3. Sack RA. The large infant. Am J Obstet Gynecol 1969; 104: 195-204.

4. Johar R, Rayburn W, Weir D, Eggert L. Birth weight in term infants: a 50-year perspective. J Reprod Med 1998; 33 : 813-6.

5. Neiger R. Fetal macrosomia in the diabetic patient. Clin Obstet Gynecol 1992;35:138-50.

6. Fetal macrosomia. Int J Gynecol Obstet 1992; 39: 341-5.

7. Bertini AM, Soares JAC, Soares JW, Taborda W. Macrossomia fetal. In: FEBRASGO (Federação Brasileira de Ginecologia e Obstetrícia), editora. Tratado de obstetrícia. Rio de Janeiro: Revinter; 2000. p. 865-7.
8. Oral E, Cagdas A, Gezer A, Kaleli S, Aydinli K, Ocer F. Perinatal and maternal outcomes of fetal macrosomia. Eur J Obstet Gynecol Reprod Biol 2001; 99: 167-71.

9. Modanlou HD, Dorchester WL, Thorosian A, Freeman RK. Macrosomia: maternal, fetal and neonatal implications. Obstet Gynecol 1980; 55: 420-4.

10. Body ME, Usher RH, McLean FH. Fetal macrosomia: prediction, risks, proposed management. Obstet Gynecol 1983; 61: 715-22.

11. McLaren RA, Puckett JL, Chauhan SP. Estimators of birth weight in pregnant women requiring insulin: a comparison of seven sonographic models. Obstet Gynecol 1995; 85: 565-9.

12. Gonen R, Spiegel D, Abend M. Is macrosomia predictable, and are shoulder dystocia and birth trauma preventable? Obstet Gynecol 1996; 88: 526-9.

13. Johnstone FD, Prescott RJ, Steel JM, Mão JH, Chambers S, Muir N. Clinical and ultrasound prediction of macrosomia in diabetic pregnancy. Br J Obstet Gynaecol 1996; 
103: 747-54.

14. Varaldi V. Fetal risk of macrosomia. Fetal Diagn Ther 2002; 17 (Suppl 1): 1-105.

15. Gonen O, Rosen DJD, Dolfin Z, Tepper R, Markov S, Fejgin $\mathrm{MD}$. Induction of labour versus expectant management in macrosomia: a randomised study. Obstet Gynecol 1997; 89: 913-7.

16. Combs CA, Singh NB, Khoury JC. Elective induction versus spontaneous labour after sonographic diagnosis of fetal macrosomia. Obstet Gynecol 1993; 81: 492-6.

17. Engin O, Cagdas A, Gezer A, Semih K, Aydinli K, Öçer F. Perinatal and maternal outcomes of fetal macrosomia. Obstet Gynecol 2001; 99: 167-71.

Submitted on July 4, 2003

Final version resubmitted on August 8, 2003

Approved on November 10, 2003 